\title{
The renewable energy household lighting for Chibayish inhabitant's in Iraq ${ }^{\star}$
}

\author{
Furat Dawood*, Tania Urmee, and G.M. Shafiullah \\ Electrical Engineering, Energy and Physics, School of Engineering and Information Technology, Murdoch University, \\ Perth, WA, Australia
}

Received: 26 April 2017 / Received in final form: 30 June 2017 / Accepted: 27 July 2017

\begin{abstract}
Affordable and clean energy is one of the major goals for global sustainable development. Lighting is a major aspect of human energy consumption and access to quality lighting is one of the most important indicators of human development. Like other countries around the world, the Iraqi government has realized the importance of climate change and the necessity for clean energy which has led them to officially ratifying the Kyoto Protocol in January 2008. However, it is challenging to implement a clean and renewable energy lighting system for a small community like Chibayish in the Iraqi marshes. The Chibayish unique house building technique of man-made islands (floating baskets), results that these floating houses are not connected to the Iraqi national grid. The villagers in Chibayish require artificial light for their indoor living areas after dark and also for night fishing, which is a common practice. In this research study, various renewable energy resources have been examined in order to identify the most locally practical renewable energy technology for household lighting needs. The solar irradiance profile in the area showed the viability of solar energy in comparison to other renewable energy sources considered within these specific environmental conditions. An analysis carried out using HOMER Pro simulator shows that the solar photovoltaic is an affordable and reliable option for this community.
\end{abstract}

\section{Introduction}

Access to lighting after dusk is a cornerstone of the social and economic development of a community [1]. Over 1.2 billion people globally do not have access to electricity [2], many of these people are living in rural and remote communities of developing countries and use diesel generators to fulfill their electricity needs. However, fossil fuel-based lighting is an inefficient way of utilizing energy and can have a negative impact on the environment and human health, safety and livelihood. Despite being a developing country, Iraq's gross domestic product is an average of $\$ 7100$ US per capita, however, $23 \%$ are still living on less than $\$ 2.2$ US a day [3].

The Iraqi marshlands (Al-Ahwar) is a unique inland delta system which is considered one of the world's largest marshlands according to the United Nations Educational, Scientific and Cultural Organization (UNESCO). Recently, Al-Ahwar has been restored resulting in a rapid rise in population [4]. The Chibayish district is one of the four wetland marsh areas in southern Iraq which has been

\footnotetext{
^ Paper presented at: World Renewable Energy Congress, WREC XVI, 5-9 February 2017, Murdoch University, Perth, Western Australia.

* e-mail: furat99@hotmail.com
}

declared a world heritage site by UNESCO and protected under the national and international laws as a natural conservation area [4]. Hence, creates a need for the development of a clean and sustainable energy system.

This research explores the techno-economic feasibility of implementing a clean and renewable energy (RE) lighting system for the small community of Chibayish in the Iraqi marshes. Initially, various renewable energy technologies (RET) are evaluated for this specific site in Chibayish to recommend the most feasible RET. Later, based on the identified RET, a techno-economic model has been developed to explore the potentialities of deploying a RE based lighting system for the community. Finally, the financial mechanism has been proposed with recommendations for successful deployment.

\section{Demographics of Chibayish area}

Fed by the Tigris and Euphrates rivers, the marshlands of Mesopotamia are spawning grounds for Gulf fisheries and home to many different species of birds. The Chibayish is one of the five districts (Qadha) in the Thi-Qar Governorate south of Iraq; which is located at latitude: $31^{\circ}$ North and longitude: $47^{\circ}$ East as shown in Figure $1(\mathrm{a})$. The Chibayish is experiencing the highest poverty and 

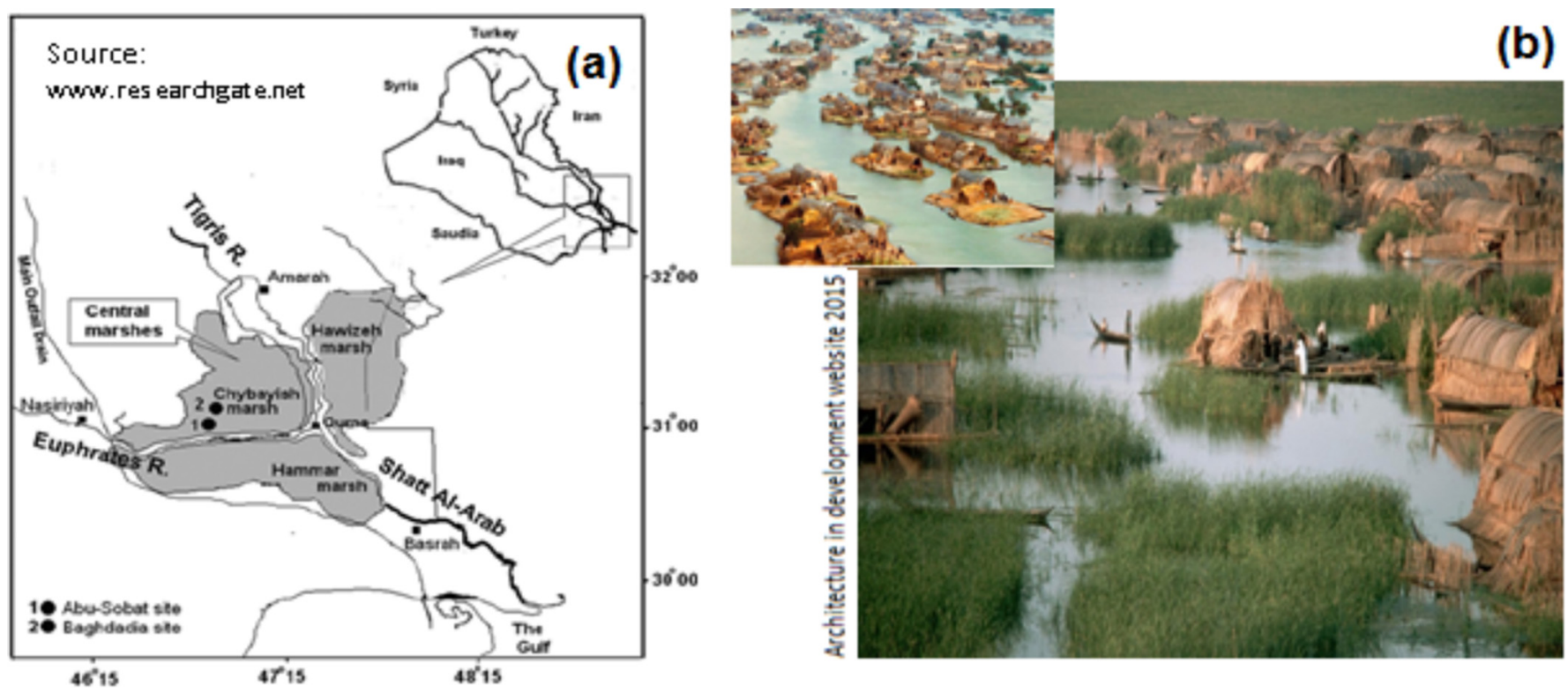

Fig. 1. Chibayish - Iraq: (a) Chibayish marsh location and (b) floating basket homes in Chibayish.

unemployment rate in the country [5,6]. In addition to its poor economic state, the area also lacks access to education resulting in widespread illiteracy particularly for women $[5,6]$. The Chibayish has an extremely hot and humid aquatic environment which provides a resting spot for thousands of wildfowl migrating between Siberia and Africa [7]. The population fluctuated during the last 60 years due to the marshes draining and other political issues. They lived in small settlements and had a largely self-sufficient economy structured around the aquatic environment. Their economy was based on the traditional occupations of fishing, cultivation, buffalo breeding and reed gathering for cane handicrafts [8]. The area is famous for its unique homes which are built on small man-made islands in the middle of the marshes as shown in Figure 1(b). These artificial floating islands are made by enclosing a piece of swamp and filling it in with reeds and mud $[9,10]$. The floating houses are called "Chibayish", where the area has got its name. As a result of the unique and isolated way that these houses were built, they have never been connected to the main electricity grid despite being surrounded by electrified towns and villages [11]. Underwater cabling was not an option due to the movement of the houses and the low population density. Hence, the people of Chibayish are forced to use old traditional biomass fuel for lighting, cooking and other energy needs as shown in Figure 2. However, some of the households use small electricity generators running on conventional fossil fuels which are noisy, polluted and expensive to run. On 17 July 2016, the Chibayish as a part of Al-Ahwar, was named a UNESCO World Heritage Site [12], and consequentially became a natural conservation area [4]. The Iraqi government realizes climate change issues and the necessity for clean energy after officially ratified the Kyoto Protocol in January 2008 [7]. The need for a clean and sustainable stand-alone source of power for Chibayish dwellings arises to minimize the impact on the biodiversity and ecosystem.

\subsection{Current lighting systems in Chibayish}

Electricity access in Thi-Qar is mainly from private generators [13]. Eight percent of the local population have no access to the electricity grid and have no alternative electricity source; half of this figure live in Chibayish $[5,6]$. Currently, the Chibayish villagers use kerosene mantle lantern (Fig. 2(a)), kerosene lantern (Fig. 2(b)), or an open fire (Fig. 2(c)) for lighting [7]. The use of portable torches which are run by disposable dry cells is also a common practice (Dawood, personal communication, 20 September 2016). There is a wide range of problems, hazards and environmental impacts associated with the current lighting system in Chibayish. Kerosene lanterns and indoor open fire (Fig. 2), produce high levels of air pollution inside the house resulting in a range of health-damaging pollutants such as smoke, ash and soot particles. In poorly ventilated dwellings; toxic products in smoke are the significant cause of morbidity, mortality, respiratory diseases and eye problems in this community [14]. Portable mantle lanterns are used when lighter luminous is needed for work inside the house or in night fishing (Fig. 2(a)) [15]. They are hazardous because they carry them around in the boats with pressurized kerosene. Liquid fuel spills due to unsafe transport, storage or accidental leakage have significant environmental impact. Battery operated torch lights and lanterns are considered a safe and clean source of light. However, they are very costly to run. Villagers usually dispose of the used batteries in the water due to the lack of environmental awareness knowledge and the unavailability of the secure disposable system. The private electricity generator's fuel cost and fuel leakage accidents increase the hazards associated with these generators. The noise from these generators has a negative impact on the biodiversity, especially the birds in the area [16].

Some of the data was collected through personal contacts in Iraq on the 20th of September 2016, to determine the daily kerosene consumption and the local 

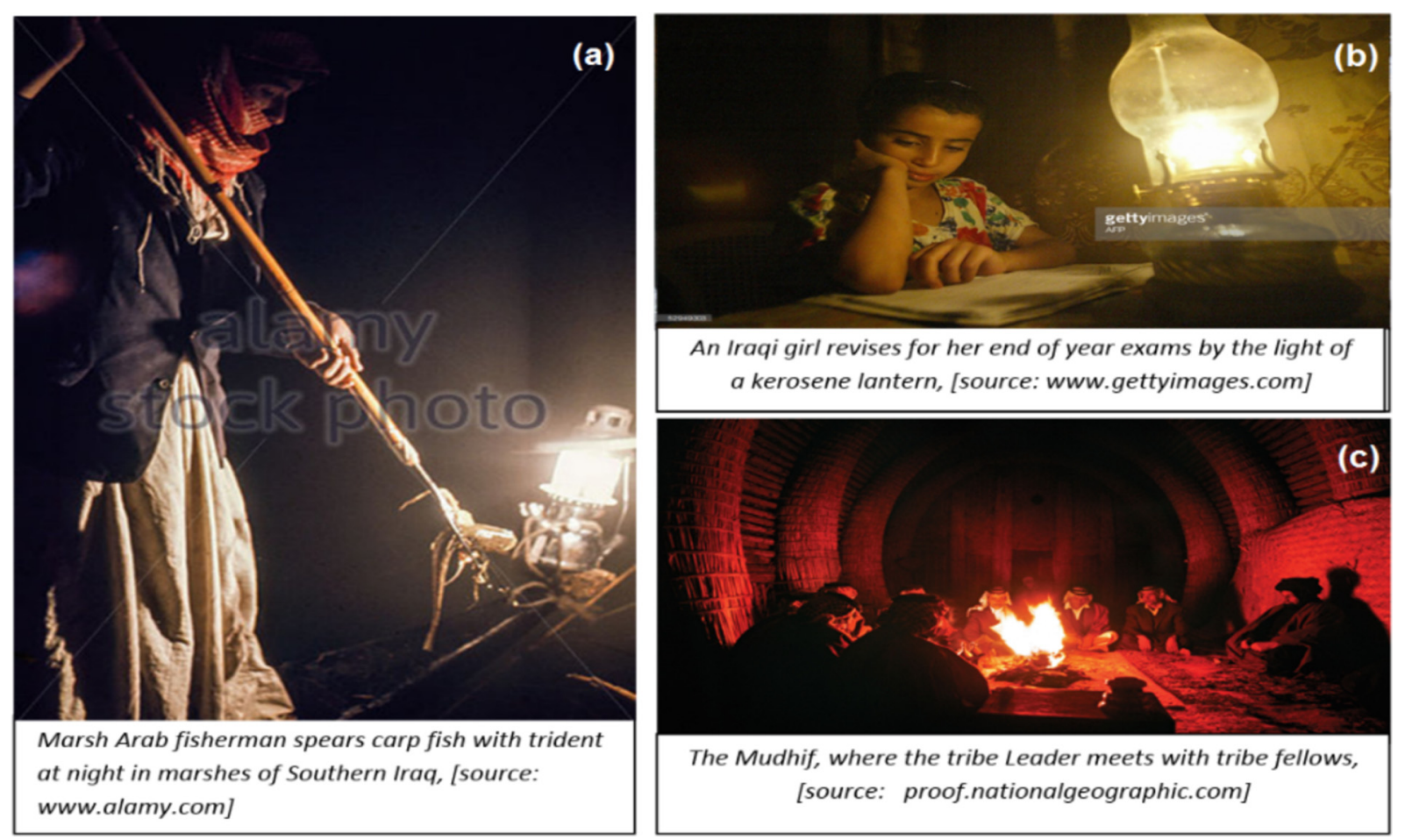

Fig. 2. Chibayish villagers lighting and night fishing: (a) kerosene mantel lantern; (b) kerosene lantern; and (c) open fire.

prices. It was found that the average small house uses two kerosene lanterns indoors for about $6 \mathrm{~h}$ daily and one portable mantel lantern for night work. Hence, the kerosene consumption is an average of $1 \mathrm{~L}$ per day for lighting purposes depending on the light intensity needed (Dawood, personal communication, 20 September 2016).

The price of kerosene from the subsidized ration by the government is $10 \mathrm{US}$ cents per litre plus the transport cost. However, this rationed quantity is fixed for each household regardless the family members and is usually not enough. The kerosene prices in the open market is currently at least $250 \%$ more expensive compared to the government subsidized ration. Thus, it costs 25 US cents per litre plus the transport cost (Dawood, personal communication, 20 September 2016). Hence, the average daily expenses for kerosene are about 20 US cents per day, resulting in monthly expenses of $\$ 6$ US.

\section{Methodology}

Figure 3 summarizes the step by step methodological approach for the proposed system. The different RET have been evaluated using the National Aeronautics and Space Administration (NASA) resources data records, technical issues, the social and cultural conditions of installing these technologies to determine the most feasible technology for the Chibayish area. The techno-economic model was developed with the best suitable RET, i.e., solar photovoltaic (PV) using HOMER Pro simulation software. The specifically designed solar PV home system for lighting was simulated according to different system component sizes and autonomy capacity. The financial mechanism and repayment calculations have been conducted using a spreadsheet for different microloans options and affordability. This economic effectiveness can be a real incentive in the acceptability of this technology transfer. Thus, it is to compare the monthly cost of the kerosene consumption for lighting with the monthly loan payments and the loan period for the suggested solar PV lighting system.

\subsection{Renewable energy technologies assessment for Chibayish}

There are many different RET available however, many of them are not practicably applicable. In order to assess the most viable RE source, issues related to health and safety, environment, government policy, future growth, implementation facility, the cost of implementation, operation and maintenance cost, carbon cost (if any) must be considered. Based on theses criteria a suitable RET has been proposed to implement RE based lighting system for Chibayish.

\subsection{Techno-economic model}

\subsubsection{Solar irradiance and challenges around Chibayish area}

Solar energy in Iraq generally has an average irradiation of $5.6 \mathrm{kWh} / \mathrm{m}^{2}$ per day and more than 2300 sunny hours per year [17]. NASA data show that Chibayish has an average of $5.18 \mathrm{kWh} / \mathrm{m}^{2}$ and a temperature range of $11.29-36.32^{\circ} \mathrm{C}$. There are also serious environmental challenges to account for such as dust storms, high humidity and ambient temperatures, particularly in the summer season [18]. 


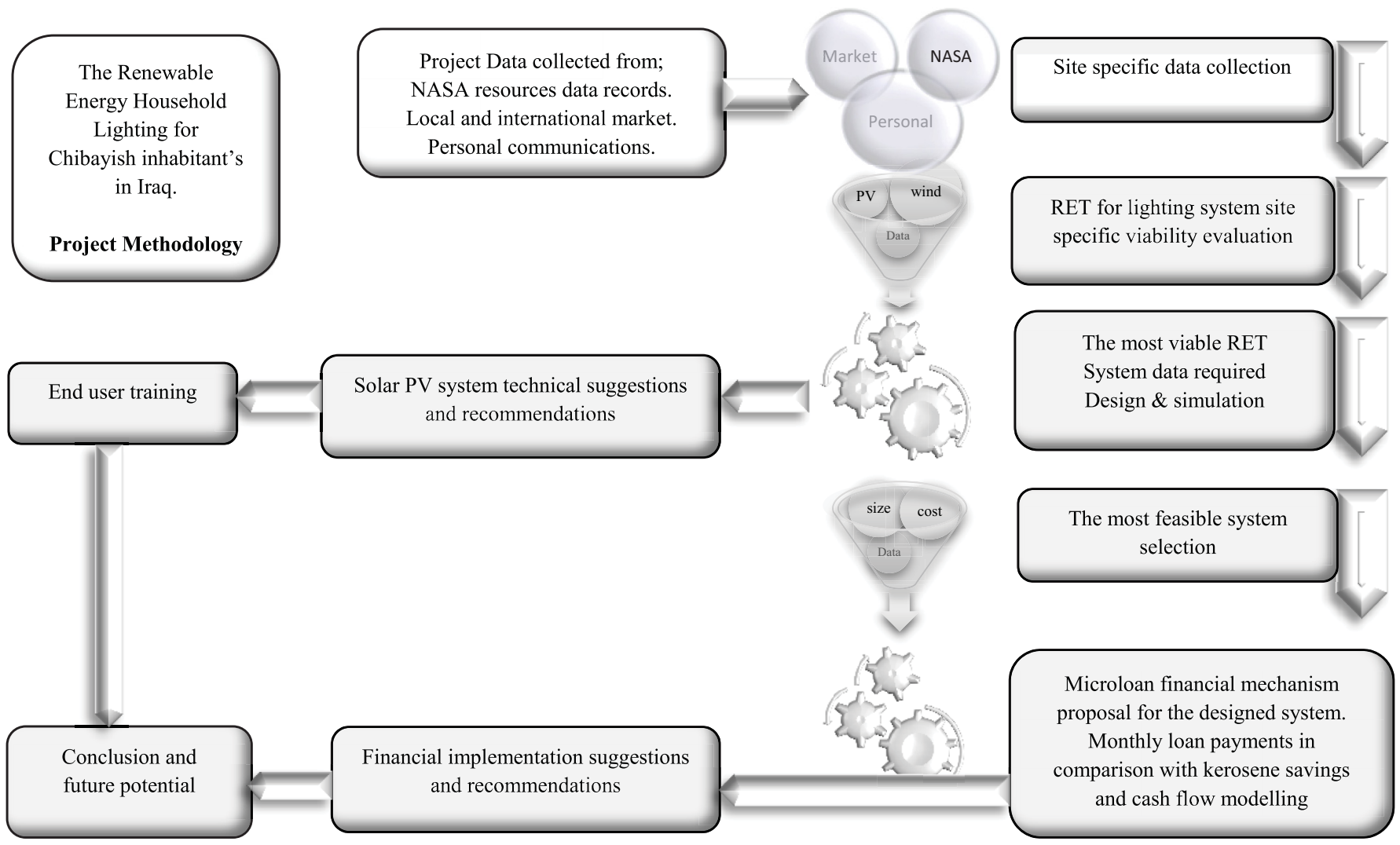

Fig. 3. Project methodology flow chart.

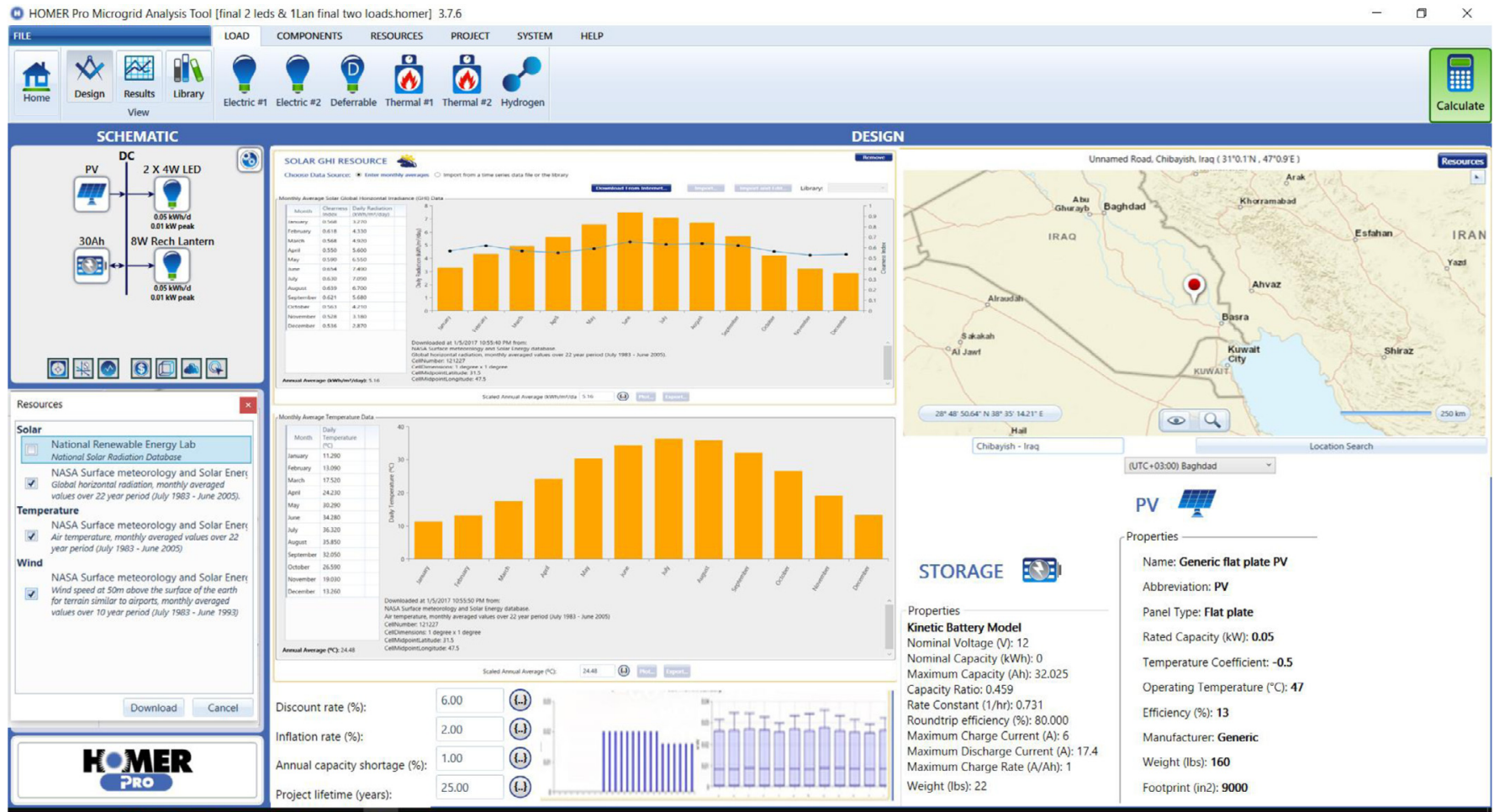

Fig. 4. Screen capture for the data inputs to Homer renewable energy simulation software. 
Table 1. HOMER Pro simulator inputs (data, parameters and assumptions).

\begin{tabular}{|c|c|}
\hline Design parameters and factors & Proposed solar PV system \\
\hline Average daily load in Wh $(4 * 2 * 6 \mathrm{~h}+8 * 1 * 4 \mathrm{~h})$ & $80 \mathrm{Wh}$ \\
\hline $\begin{array}{l}\text { Energy required from the solar PV panel estimation for } \\
\text { average daily radiation }\left(5.18 \mathrm{kWh} / \mathrm{m}^{2} / \text { day }\right) \text { [18], SPV } \\
\text { panel price } \sim \$ 1 \mathrm{US} / \mathrm{Wp}\end{array}$ & $\begin{array}{l}\text { Load Wh } /\left(0.585^{*} \text { average peak sun hours }\right) \\
26.4 \mathrm{Wp} \\
\sim 30 \mathrm{Wp}\end{array}$ \\
\hline $\begin{array}{l}\text { DC charging regulator charges the battery and the lantern } \\
\text { during the day, supply the LED lights only } \\
\text { during the night }\end{array}$ & $\begin{array}{l}\text { Overcharge protection circuit } \\
\text { Local made/imported }\end{array}$ \\
\hline Battery size for 3 days autonomy & $($ Daily load $\mathrm{Wh} * 3 / 12 \mathrm{~V}) /\left(\dot{\eta}_{\text {Battery }} * \mathrm{DoD}\right)$ \\
\hline Battery efficiency $\dot{\eta}_{\text {Batteryis }}=80 \%$ and $\mathrm{DoD}=50 \%$ & $50 \mathrm{Ah}$ \\
\hline Iraqi local market prices [19] & Price $\sim \$ 60$ US \\
\hline Nominal interest rate/inflation rate in Iraq [20] & $6 \% / 2 \%$ \\
\hline Project proposed lifetime (estimated PV panel lifetime) & 25 years \\
\hline Solar PV panel and DC charging regulator lifetime & 25 years \\
\hline Low maintenance battery lifetime (sealed lead-acid) & 5 years \\
\hline Yearly operating and maintenance cost in USD (e.g. cleaning) & $\$ 5$ \\
\hline Installation, panel frame and wiring cost in USD & $\$ 50$ \\
\hline $4 \mathrm{~W}$ LED globe (number/total cost USD/life time in years) & $2 / \$ 8 / 10$ years \\
\hline $\begin{array}{l}8 \mathrm{~W} \text { solar rechargeable lantern } \\
\text { (number/total cost USD/lifetime in years) }\end{array}$ & $1 / \$ 15 / 3$ years \\
\hline
\end{tabular}

\subsubsection{Solar PV system design}

As stated earlier, RE based lighting systems have been designed with HOMER Pro, and different system's capacities will be carried out. Based on the current lighting uses pattern, a daily load profile consists of two types of load components was considered to design the PV system. A minimum system consists of a $30 \mathrm{~W}$ solar PV module with two $4 \mathrm{~W}$ light emitting diode (LED) bulbs and one $8 \mathrm{~W}$ rechargeable lantern is designed based on the minimum light required for an average household. The solar radiation data was imported from NASA surface meteorology and solar energy database into the HOMER Pro Simulator as shown in Figure 4. A standard solar PV panel from the software library was used, and storage battery banks were adjusted according to the availability in the local market and technical specifications.

\subsubsection{System design and simulation}

Based on the proposed load pattern, the system is intended to use the minimum solar PV panel power capacity and the minimum battery bank size to supply 3 days autonomy according to the specific site data and resources. The system has been designed according to the average solar radiation in Chibayish based on the load profile and the input parameters required for the HOMER Pro simulator as shown in Figure 4.

Table 1 summarizes the proposal assumptions, the adjusted capacities and prices according to the collected data from International markets [21], the Central Bank of Iraq website $[20]$ and through personal contacts (Dawood, personal communication, 20 September 2016).

\subsection{Financial mechanism and recommendation}

A detailed financial mechanism will be developed to explore the financial viability of the proposed system by identifying life cycle costs, payback period and simple net cash flow. The micro-finance mechanism with simple fixed monthly repayments could be a very simple way for the small scale financing [22]. The financial mechanism with microloan system has been investigated under this scheme and necessary recommendations have been provided for implementation.

\section{Results and analysis}

\subsection{Renewable energy technologies assessment for Chibayish}

The option of a microgrid with a central RE plant is not an option due to distribution difficulties associated with the continuous movement of the houses and the low population density. The use of wind turbines is impractical because of the installation challenges involved and the high density of birds in the area. Biofuel could substitute the current kerosene fuel for lighting, however, while this technology would benefit the environment in general; it does not resolve the current indoor lighting issues. There are also no waves, currents or tides in this area meaning that related technologies are not a viable option either. Whilst the use of fuel cell technology improves the environmental and health related risks, its fuel related dangers and high initial cost make it an impractical solution. Hence, based on the solar radiation in the area and with consideration to cost effectiveness, solar energy is the most viable solution for this small scale indoor lighting system. 
Q5 Table 2. Optimisation results for the proposed system simulation tabulated results.

\begin{tabular}{|c|c|c|c|c|c|c|c|c|c|c|c|}
\hline $\begin{array}{l}\text { Architect- } \\
\text { ure PV } \\
\text { panel } \\
(\mathrm{kW})\end{array}$ & $\begin{array}{l}\text { Architect- } \\
\text { ure } 50 \mathrm{Ah}\end{array}$ & $\begin{array}{l}\text { Architecture } \\
\text { dispatch }\end{array}$ & $\begin{array}{l}\text { Cost } \\
\text { NPC } \\
(\$)\end{array}$ & $\begin{array}{l}\text { Cost } \\
\text { initial } \\
\text { capital } \\
(\$)\end{array}$ & $\begin{array}{l}\text { Cost } \\
\text { O\&M } \\
(\$)\end{array}$ & $\begin{array}{l}\text { System } \\
\text { cap } \\
\text { short } \\
\text { (kWh/ } \\
\text { year) }\end{array}$ & $\begin{array}{l}\text { System } \\
\text { Elec } \\
\text { Prod } \\
\text { (kWh/ } \\
\text { year) }\end{array}$ & $\begin{array}{l}\text { PV } \\
\text { panel } \\
\text { DC } \\
\text { capacity }\end{array}$ & $\begin{array}{l}\mathrm{PV} \\
\text { panel } \\
\text { capital } \\
\text { cost }(\$)\end{array}$ & $\begin{array}{l}50 \mathrm{Ah} \\
\text { quantity }\end{array}$ & $\begin{array}{l}50 \text { Ah } \\
\text { autonomy } \\
\text { (h) }\end{array}$ \\
\hline 0.03 & 1 & Reg & 496.314 & 188 & 5 & 0.5972423 & 44.42997 & 0 & 30 & 1 & 77.43371 \\
\hline 0.04 & 1 & Reg & 506.314 & 198 & 5 & 0 & 59.23997 & 0 & 40 & 1 & 77.43371 \\
\hline
\end{tabular}

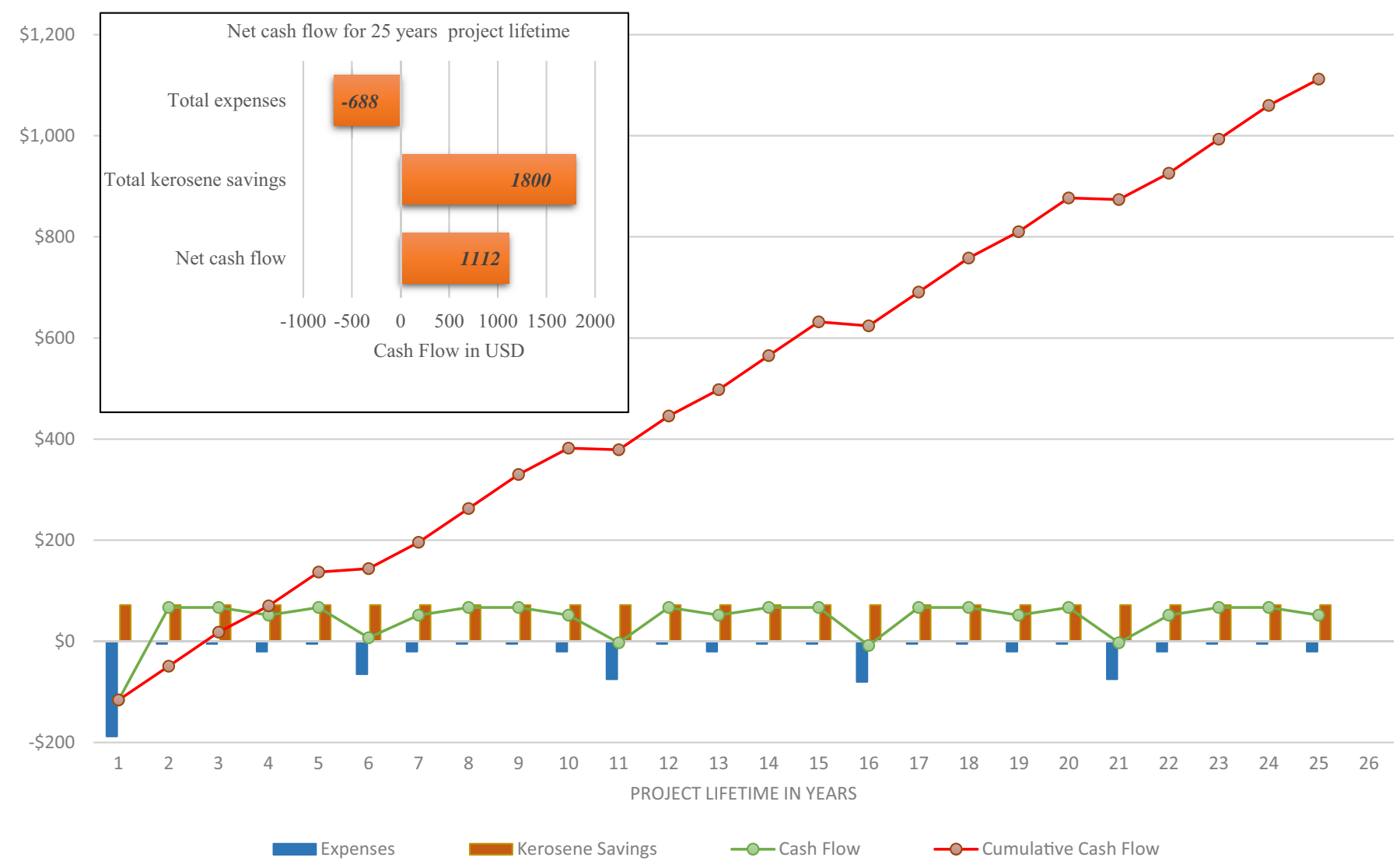

Fig. 5. System lifetime's nominal, cumulative and net cash flow.

In the past few years, solar PV systems have witnessed drastic improvements to their conversion efficiency and affordability $[1,23,24]$. In general, solar PV lighting systems offer many advantages, and they can improve lighting levels by $100-1000 \%$ in comparison to kerosene[22]. In addition to all the environmental, health and social benefits; it is safe, reliable, modular and low maintenance which technically makes it "the suitable method for rural life"[23]. However, the dusty weather in Chibayish may incur more frequent cleaning, whilst the high ambient temperature may reduce the efficiency and lifetime cycle of the PV panels, wires and battery bank. Hence, special attention is required in selecting the right materials capable of withstanding the harsh weather conditions in the area. The battery bank will also need to be kept in a well-ventilated and sheltered housing.

\subsection{Techno-economic model}

The simulation results shown in Table 2 , indicate that the minimum feasible solar PV panel power capacity is $30 \mathrm{~W}$ with acceptable capacity shortage during the worse irradiance periods throughout the year. The system voltage is $12 \mathrm{~V}$, and the battery bank size found to be at least $50 \mathrm{Ah}$ capacity to secure 3 days of autonomy.

The initial cost according to the average prices of the international market is $\$ 188$ US plus some component replacement costs throughout the estimated project lifetime of 25 years (Tables 1 and 2). The project cash flow diagram and kerosene cost savings are shown in Figure 5. The simple cash flow graph indicates that the initial cost payback period is less than 3 years. The simple cumulative cash flow in Figure 5, for the system's entire lifetime of 25 years is found to be a benefit of $\$ 1112$ US of 


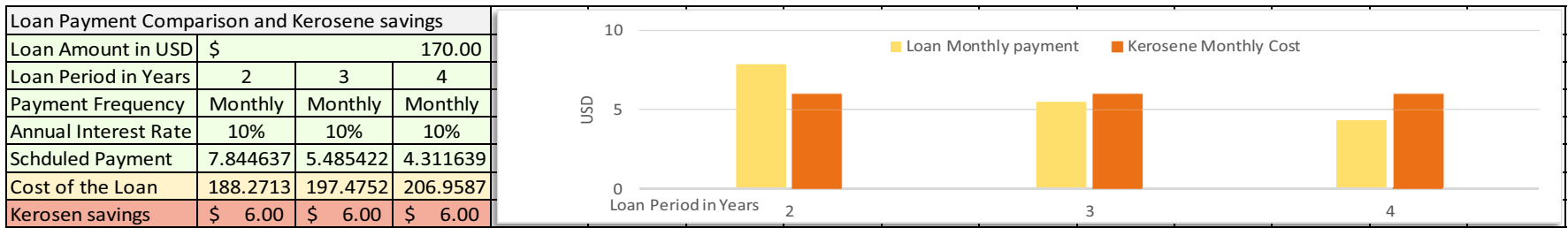

Fig. 6. Microloan monthly payments spreadsheet calculations.

the substituted kerosene cost. It is also possible to expand the solar PV system size according to the end user's needs by adding or replacing modules. As an added benefit, such expansions in the load are not fully reflected in the initial cost due to the similar installation fees and associated maintenance.

\subsection{Financial mechanism and recommendations}

Cost effectiveness is an important incentive for the adoption of RET, yet the initial start-up costs tend to be relatively high in low socio-economic areas. Hence, the use of microloans offers a simple and practical solution to implementing small-scale RE projects. Figure 6 shows the calculation's spreadsheet for the microloan fixed payments by comparing the kerosene expenses of 6 USD per month for the proposed system to determine the optimal loan payback period. Assuming that charging an annual interest rate of $10 \%$ is viable for the financial institutions, a 3-year microloan with a reasonable percentage upfront payment (e.g. 10\%) was found to be economically feasible and will not incur any additional costs in comparison to conventional kerosene consumption. The microloan percentage upfront payment will also create ownership resulting in increased awareness and care. The payback period for the loan will be decided by adjusting the monthly repayments comparable to the Kerosene cost in the previous conventional system. This microloan could be connected to one of the government support programs to reduce the repayments collection cost and ensure the success. In order to demonstrate this system and avoid over expectations, it is important to install it in a display house and offer locals the opportunity to learn more about the benefits it offers. End user training for both consumers and local technicians will ensure this project's long-term success and offer access to after-sale services.

\section{Conclusions}

The fuel-based lighting system currently in Chibayish, has had an adverse impact on the inhabitant's livelihoods and has polluted the environment. Some RE resources have been examined to find the most locally practicable RE technology for household lighting needs. The solar irradiance profile in the area showed the viability of solar power, among the other RE sources, examined in the particular site environmental conditions. The solar home system (SHS) feasibility for the proposed lighting system concluded that the SHS is affordable and can pay back for itself, in a relatively short period. The availability of some locally made parts component for the designed lighting system in the local market may reduce the cost and improve the after sale services and warranty procedure. The financial mechanism has to be intended to ease the repayment and encourage the end users to adopt the new technology. There is a potential for cost-effective, holistic household electrification by solar PV small-scale StandAlone Power Systems. As Chibayish, the next step is to go entirely green by converting the boat's petrol fueled engines to electric motors.

\section{References}

1. T. Urmee, D. Harries, H.G. Holtorf, Photovoltaics for Rural Electrification in Developing Countries, A Road Map, Chapter 2 (Springer International Publishing, Switzerland, 2016)

2. IEA, World Outlook Energy (2015), p. 3, Available from: https://www.iea.org/Textbase/npsum/WEO2015SUM.pdf

3. United Nations Development Programme (UNDP) Website, Iraq (2016), Available from: http://www.iq.undp.org/con tent/iraq/en/home/countryinfo.html

4. United Nations Environment Programme (UNEP), Natural and Cultural Management of the Iraqi Marshlands Website (2016), Available from: http://marshlands.unep.or.jp/

5. United Nations Office for the Coordination of Humanitarian Affairs (OCHA) Annual Report/Iraq (2009), p. 110, Available from: https://www.unocha.org/sites/unocha/ files/OCHA\%20AR2009_Hi\%20Res_Final.pdf

6. Thi-Qar Governorate Profile, NCCI (2015), Available from: http://www.ncciraq.org/images/infobygov/NCCI_Thi Qar Governorate Profile.pdf

7. UNESCO Website (2016), Available from: http://whc. unesco.org/en/list/1481

8. The Iraqi Government Assault on the Marsh Arabs, Briefing Paper (Human Rights Watch, Washington, DC, January 2003), Available from: https://www.hrw.org/legacy/back grounder/mena/marsharabs1.htm

9. H. Partow, United Nations Environment Programme (UNEP), The Mesopotamian Marshlands: Demise of an Ecosystem (2001), Available from: http://eoimages.gsfc. nasa.gov/images/imagerecords/1000/1716/meso2.pdf

10. G. Broadbent, The Ecology of the Mudhif (WIT Press, University of Portsmouth, UK, 2008), Vol. 113, Available from: https://www.witpress.com/Secure/elibrary/papers/ ARC08/ARC08002FU1.pdf

11. UNHCR, Needs Assessment of Recently Displaced in AlChibayish District, Thi-Qar Governorate (2007), Available from: http://www.unhcr.org/462cc68c2.pdf 
12. Wetlands International Website (2016), Available from: https://www.wetlands.org/casestudy/conserving-and-re storing-the-iconic-marshes-of-southern-iraq/

13. T. Vishwanath, D. Sharma, N. Krishnan, B. Blankespoor, Where are Iraq's Poor? Mapping Poverty in Iraq (World Bank Group, Washington, D.C., 2015), Available from: http://documents.worldbank.org/curated/en/88980146818 9231974/pdf/97644-WP-P148989-Box391477B-PUBLIC-Ir aq-Poverty-Map-6-23-15-web.pdf

14. World Health Organization (WHO), Fact sheet $\mathrm{N}^{\circ} 292$ (2016), Available from: http://www.who.int/mediacentre/ factsheets/fs $292 / \mathrm{en} /$

15. A.J. Laith, Fishing gear and methods of the lower Mesopotamian plain with reference to fishing management, Mar. Mesop. Online 1, 1 (2006)

16. L.R. Autumn, The Effect of Noise on Wildlife: A Literature Review (2007), Available from: http://www.htoplanning. com/docs/Other $/ 980000 \%$ 20Radle,\%20The\%20Effect\%20of $\%$ 20Noise\%20on\%20Wildlife_\%20A\%20Literature\%20 Review.PDF
17. International Renewable Energy Agency Website (IRENA) (2016), Available from: http://resourceirena.irena.org/gate way/countrySearch/? countryCode $=\mathrm{IRQ}$

18. NASA Website (2016), Available from: http://earthobserva tory.nasa.gov/IOTD/view.php?id=86539

19. State Battery Manufacturing Comp (SBMC), Ministry of Industry \& Minerals, Republic of Iraq, Website (2016), Available from: http://www.sbmc.industry.gov.iq/index1.htm

20. Central Bank of Iraq CBI (2016), Available from: http:// www.cbi.iq/

21. Made in China Website (2016), Available from: http://www. made-in-china.com

22. REEEP, Modern Lighting for Microfinance Clients Around the Globe (2009)

23. UNEP, Current Status of Renewable Energies in the Middle East - North African Region (2007), Available from: http:// www.unep.org/pdf/rowa/Renewable_Energy.pdf

24. T. Urmee, Md. Anisuzzaman, Social, cultural and political dimensions of off-grid renewable energy programs in developing countries, Renew. Energy 93, 159 (2016).

Cite this article as: Furat Dawood, Tania Urmee, G.M. Shafiullah, The renewable energy household lighting for Chibayish inhabitant's in Iraq, Renew. Energy Environ. Sustain. 2, 15 (2017) 